\title{
TENDÊNCIAS DO M-LEARNING NA EDUCAÇÃO BÁSICA E O DESENVOLVIMENTO DE COMPETÊNCIAS PARA O SÉCULO 21
}

\section{TRENDS OF M-LEARNING IN BASIC EDUCATION AND COMPETENCIES DEVELOPMENT FOR THE 21ST CENTURY}

\author{
Carlos Fernando de Araújo Junior \\ Cruzeiro do Sul University, carlos.araujo@cruzeirodosul.edu.br \\ Eduardo Jesus Dias \\ Cruzeiro do Sul University, eduardo091@gmail.com \\ Carmen Lucia Tozzi Mendonca Conti \\ Franca University, carmen.conti@unifran.edu.br \\ Marcos Andrei Ota \\ Cruzeiro do Sul University, ota.marcos@gmail.com
}

\section{Resumo}

Este estudo propõe um mapeamento da literatura sobre a pesquisa e uso de m-learning nos campos da Ciência e da Matemática, com foco na Educação Básica, buscando identificar tendências na produção brasileira e a promoção de competências para o século XXI. Para tanto, trabalhos acadêmicos e científicos de língua portuguesa foram investigados no período de 2014 a 2016. Trata-se de um estudo exploratório, com análise descritiva apoiado em referenciais bibliográficos e empíricos, utilizando questionários de pesquisa baseados em uma avaliação quantitativa, em três Escolas brasileiras no estado de São Paulo, em diferentes níveis de desenvolvimento de estratégias de aprendizagem, utilizando m-learning em seus respectivos projetos institucionais. Diante da coleta de dados e dos resultados, destaca-se o mapeamento da literatura (categorização dos trabalhos por núcleo temático e sub-núcleo) e a pesquisa realizada com alunos, professores e gestores. Ambos os cenários nos permitem ter uma visão panorâmica sobre o uso de m-learning e, principalmente, considerar a percepção dos participantes no papel do m-learning no desenvolvimento de competências para o século XXI.

Palavras-chave: M-learning, Mapeamento, Educação Básica, Competências.

\begin{abstract}
This study proposes a mapping of literature on the research and use of m-learning in the fields of Science and Mathematics, focusing on Basic Education, seeking to identify trends in Brazilian production and the promotion of competences for the 21st century. In order to do so, Portuguese language academic and scientific papers were investigated covering
\end{abstract}


the period from 2014 to 2016 . This is an exploratory study, with descriptive analysis supported by bibliographical and empirical references, using survey questionnaires based on a quantitative evaluation, in three private Brazilian schools in the state of São Paulo, in different levels of learning strategies development, using m-learning in their respective institutional projects. In face of data collection and results, we highlight the literature mapping (categorization of the works by thematic core and sub core) and the research carried out with students, teachers and managers; both scenarios allow us to have a panoramic view about the use of m-learning and, mainly, to consider the participants' perception in the role of m-learning in the development of competences for the $21 \mathrm{st}$ century.

Keywords: M-Learning, Mapping, Basic Education, Competencies.

\section{Introduction}

Mobile learning (m-learning) has developed in a very profitable way in recent years and has emerged as an important form of educational practices transformation, especially in Basic Education (Unesco, 2012; West, Chew 2014; Crompton, Burke and Gregory, 2017). M-learning can be an important ally to emerging pedagogical practices of active learning (Smith et al, 2005; Baepler, Walker, Driessen, 2014), Flipped Classroom (Bishop and Verlarger, 2013), Blended Education (Garisson, Vaughan, 2008) and in the formation of competences considered hard - specific knowledge of disciplinary nature and soft skills and abilities - knowledge of interdisciplinary and transdisciplinary nature (Binkley et al, 2012).

Several recent works have highlighted the potential of m-learning for the development of specific skills and abilities. In particular in the Mathematics (Crompton, 2015; Arantes and Seabra, 2016) and Science (Crompton, 2016; Honorato et al, 2015) fields. Nevertheless, few works have explored m-learning for contextual and situated learning aiming at the promotion of skills and abilities for the 21st century such as: creativity, innovation, problem solving, complex thinking, learn to learn, communication, collaboration, digital literacy, life and career, local and global citizenship formation (Binkley et al, 2012; Crompton, 2017). M-learning best result should consider its transversal use in and outside the classroom in conjunction with other methodologies and teaching and learning strategies that take into account students' characteristics.

Recent developments in the m-learning field have pointed out the importance of this modality to integrate a more active and comprehensive teaching and learning system that spreads the domains of conventional classroom and conventional teaching and learning practices. In the Brazilian context, where the performance in the fields of Science and Mathematics in the last Program for International Student Assessment (PISA 2015) places us in 63rd. in Sciences, and in 66th. in Mathematics, and where the reduced enrollment in careers in Science, Technology, Engineering and Mathematics can jeopardize the future of scientific and technological development in the country, methodological and modality alternatives are crucial for the change of current educational environment. 
In this work we present a mapping of the research literature and use of m-learning in the area of Sciences and Mathematics, focusing on Basic Education, seeking to identify trends in Brazilian production and the promotion of 21 st. century skills. For an empirical analysis, we used the Survey methodology, based on a quantitative evaluation, in three private schools in the state of São Paulo, at different stages of learning strategies development using m-learning, in order to identify current uses, the alignment of these uses with the perspective of 21 st century competencies, and the perception of students, teachers and managers about the role of this modality in these schools. The resulting data allow a panoramic view of the m-learning current uses and, mainly, consider the participants' perception in the role of m-learning in the development of skills for the $21 \mathrm{st}$. century, indicating its positive aspects, fragilities and the need for new study directions and developments.

\section{Literature Mapping}

In this section we carry out a mapping of the literature making use of thematic core (Fiorentini, 1994). This, in turn, is to investigate publications that deal with Mobile Learning (m-learning) in teaching and learning situations, with emphasis on teaching Science and Mathematics in Basic Education. From this perspective, we sought to understand how mobile devices have been used in teachers' practices. In order to accomplish such mapping, we consider the academic and scientific works written in Portuguese and published in the period from 2014 to 2016 . The purpose of the mapping is to identify the main areas and subareas of knowledge production in the m-learning research in Brazil and to verify its consonance with the emerging trends at international levels.

The data mapping was organized in two phases: i) the choice of relevant repositories in Portuguese language and the establishment of search criteria; and ii) the exploration of the developed work in the m-learning approach, thus investigating productions that establish a development in the fields of Science and Mathematics in Basic Education.

We consider as main bases or research repositories: Capes Database for Thesis and Dissertations, Capes Journal Portal, Renote Magazine and Annals CBIE/SBIE once we consider these the most representative ones.

The descriptors delimitation (title, subject, abstract) used the terms: Mobile learning, Teaching of Sciences and Mathematics, Basic Education and Tablets. The scientific and academic production model: congress/conference articles, scientific journals, master degree dissertations and thesis.

Initially we identified a total of 198 works, however, after adopting the search criteria and a search in the main indexes considering the established question in the proposed work (M-learning in the classroom > Teaching Science and Mathematics > Basic Education > tablet), we limited our analysis to a total of 43 publication (2014 to 2016). 
Table 1. Selected works distribution in the several databases.

\begin{tabular}{|l|l|l|l|l|}
\hline \multicolumn{5}{|c|}{ Selected works } \\
\hline Database & $\begin{array}{l}\text { No. of } \\
\text { works }\end{array}$ & 2014 & 2015 & 2016 \\
\hline Dissertations and Thesis & 9 & 3 & 2 & 4 \\
\hline Capes Journal & 5 & 1 & 0 & 4 \\
\hline Renote Magazine & 17 & 6 & 4 & 7 \\
\hline Cbie/Sbie Annals & 12 & 3 & 1 & 8 \\
\hline total & 43 & 13 & 7 & 23 \\
\hline
\end{tabular}

Source: Research Authors

According to Romanowski and Ens (2006) the manifested data of a mapping provide a global perspective of the productions in the field,and allow to point out existing transformations and gaps to the researchers in their academic analysis.

In this trend, we consider the following data: 1) descriptive data that would be the title of the article, keywords, abstract, year of publication, area of concentration, origin. 2) thematic data such as thematic core, objectives, methodology, theories, contributions and results.

The forty-three papers analysis allowed their categorization in terms of a general core and its sub core, as presented in Table 2. The articles are categorized within each core and sub core and the complete rapport can the obtained through the link (\#).

Table 2. Publications Categorization according to their core and sub core

\begin{tabular}{|c|c|c|}
\hline \multicolumn{3}{|c|}{ Categorization } \\
\hline CORE & SUB CORE & ID \\
\hline \multirow[b]{2}{*}{ Institutional Project } & Digital Inclusion & \multirow{2}{*}{$\begin{array}{l}1,2,3,8,14,15,20,28,30,31,32 \\
33,35,38,41\end{array}$} \\
\hline & Teacher training & \\
\hline \multirow{5}{*}{$\begin{array}{l}\text { Teaching and } \\
\text { Learning Strategies }\end{array}$} & Motivation & \multirow{5}{*}{$\begin{array}{l}2,3,4,5,7,9,10,11,12,13,16,17 \\
18,19,21,22,23,24,25,26,27,29 \\
30,34,35,36,38,39,40,42,43\end{array}$} \\
\hline & Customization & \\
\hline & Collaborative Activities & \\
\hline & Content Production & \\
\hline & Evaluation & \\
\hline \multirow[b]{2}{*}{$\begin{array}{l}\text { Theories and } \\
\text { Methodologies }\end{array}$} & Theories Uses & \multirow[t]{2}{*}{$6,7,11,13,21,35,36,38,39,40$} \\
\hline & Methodologies Uses & \\
\hline
\end{tabular}

Source: Research Authors 
Based on this analysis, we could find 36 papers related to High School in the scope of digital inclusion, teacher training and activities that explored teaching and learning strategies making use of theories and methodologies in the classroom. Another aspect was the identification of 15 works related to Elementary School that also explored from digital inclusion and the teacher training to the use of teaching strategies in this stage of Basic Education. In the mapping we found only 4 publications related to children's teaching, considering teacher training (Institutional Project) and student motivation (Teaching and Learning Strategies).

It is considered that the concentration of m-learning work in Basic Education is centered more on activities correlated to teaching and learning strategies at High School, once this is an extremely complex educational stage, in which the subjects in Science and Mathematics fields provide a fertile ground for experimentation using technology (Ritz and Fan, 2015).

Most papers dealing with Science and Mathematics handle these subjects in a most conventional and traditional way, making little use technology in face of its huge potential. This contribution is often limited due to the lack of teacher training in order to use technologies, difficulties related to school infrastructure, or issues concerning teaching and learning practices that are inadequate to the context of teaching and learning with technology (Almeida, 2016).

These results are in line with the systematic research recently published by Crompton (2017), which identified that the vast majority of published researches on mlearning uses behaviorist proposals, that is, far from the construction of knowledge and skills necessary for modern society.

However, a significant number of papers published in Brazil emphasize the role of collaboration in teaching and learning processes, making use of technology, specifically $\mathrm{m}$ learning, in the context of Basic Education in the fields of Science and Mathematics.

\section{The 21st Century Skills}

Improvements in technology, globalization, network society and the emergence of creative economy have brought differentiated demands to the world of work, far beyond the basic disciplinary skills and knowledge that schools, and general education institutions have handled during the latter century. While the knowledge and skills of basic subjects are still a challenge, especially in countries such as Brazil, they must be developed in association with or linked to new skills known as competencies for the 21st century. In 2009, companies such as Cisco, Intel and Microsoft along with an international task force initially involving six countries: Australia, Finland, Portugal, Singapore and the United States promoted the ATC21S project (Assessment Teaching of Twenty-First Skills). Among the various results of the project we have the mapping of these competences and their importance to the formation of the 21st century citizen (Binkley et al, 2012). These competencies are in line with other studies conducted by UNESCO, OECD, ISTE, among other organizations (Binkley et al, 2012, p.35) and other authors such as Trilling and Fadel (2009). In general, the competences for the 21st century according to Binkley et al (2012) are: 
1. Creativity and Innovation;

2. Critical Thinking, Problem solving, Decisions taking;

3. Learn to learn, metacognition;

4. Communication;

5. Collaboration;

6. Information Literacy;

7. TICs Literacy;

8. Local and Global Citizenship;

9. Life and Career;

10. Social and Personal Responsibility.

The importance of stimulating creativity and innovation, critical thinking and problem solving, interpersonal communication, and collaborative work have been widely debated in the world of work and training especially in the STEM (Science, Technology, Engineering and Mathematics) area. In this context the active methodologies have been the main sources of inspiration to promote some of these competences.

The main contribution of Binkley's et al work (2012), besides presenting the 21st century competences, is to highlight the importance of being fully aligned with teaching, learning and evaluation activities, as well as the necessary alignment of actions for the use of technology in education, inside and outside classroom environment in this new paradigm.

\section{Methodology}

In order to carry out this research, we have made use of the paradigm of the exploratory approach, of quantitative and applied nature. The study target group were students, teachers and managers of three schools in the state of São Paulo, belonging to the same educational group, that initiated activities to introduce the tablet in different education levels at different time periods. The CCS school has started activities with the use of tablets in Basic Education since 2012, the CPA school, in 2015, and the CSS school, in 2017. About 33 teachers currently take part in the initiative. We know that these schools make use of specific systematization in the use of this technology in the classroom, based on the integration of technological, pedagogical and content knowledge (TPACK model). Our research aim is, thus, to identify the perception of students, teachers and managers about the use of the tablet in education, in the context of the 21st century competences according to Binkley et al (2012). Table 3 presents the scope of the target group involved in the three schools. 
Table 3: Research Target Group List

\begin{tabular}{|l|c|c|c|c|}
\hline Schools & $\begin{array}{c}\text { Elementary } \\
\text { Students I }\end{array}$ & $\begin{array}{c}\text { Elementary } \\
\text { students II }\end{array}$ & $\begin{array}{c}\text { High school } \\
\text { students }\end{array}$ & Teachers \\
\hline CCS & 113 & 80 & 77 & 10 \\
\hline CAP & 124 & 181 & 81 & 16 \\
\hline CSS & & 26 & 38 & 7 \\
\hline Total & 237 & 287 & 196 & 33 \\
\hline
\end{tabular}

Source: Research Authors

As a research tool for data collection a questionnaire was used with responses on a likert scale from 1 to 6 (I strongly agree, I agree, I tend to agree, I tend to disagree, I disagree, I totally disagree).

\section{Results}

This study involved 711 students from three schools in the state of São Paulo, at Elementary levels 1 and 2 and High School, besides 33 teachers. For the purposes of identity preservation, we will use the acronyms CCS, CSS and CAP to designate such places located: in the city of São Paulo (CCS), in the northern seashore region of the state (CSS) and in the countryside of the state (CAP).

Figure 1 represents the data collected for the CCS school, located in the city of São Paulo. In the perspective of the students of different levels of education (Elementary 1 CCS (F1), Elementary 2, CCS (F2), High School, CCS (M), and also teachers, CCS (P)). The data represents an average for the responses for each of the ten items considered as competences for the 21st century according to Benkley et al (2012). From Figure 1, we can see that students at Elementary level 1 are, in general, the ones that best evidence the competences at teaching and learning activities carried out with the use of tablets, followed by Elementary 2 and High School students, respectively.

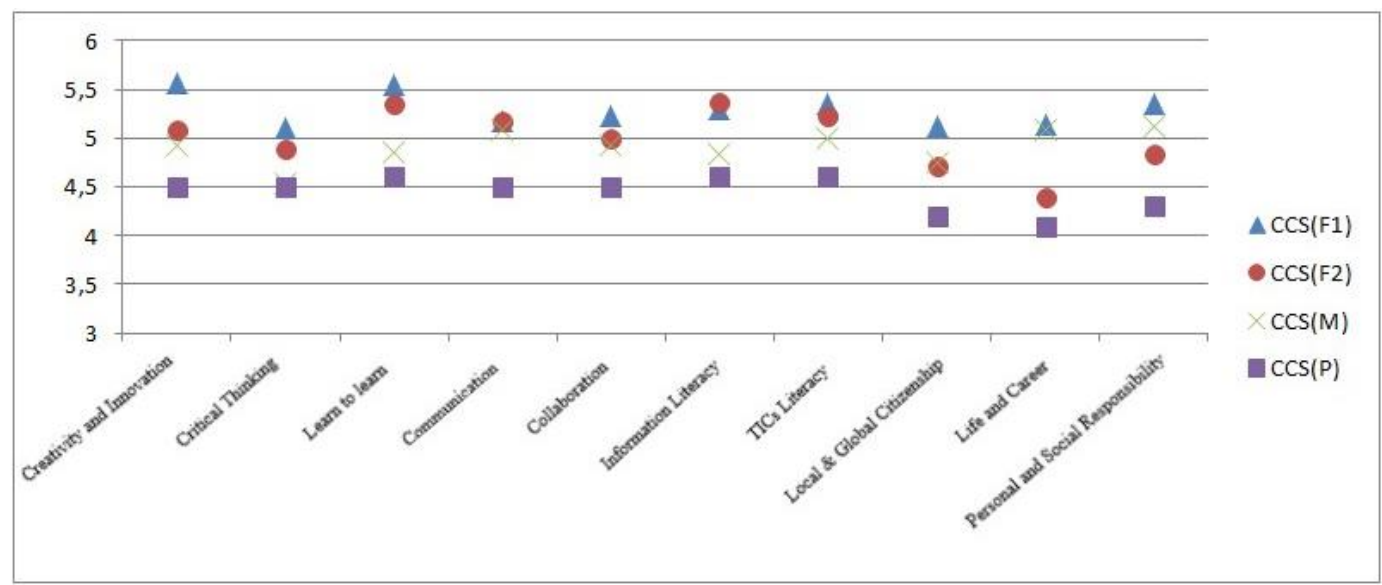

Figure 1: Observed students' average distribution and teachers' self-evaluation related to teaching and learning activities carried out with the use of tablets at different levels of education (CCS school) 
In the same Figure 1, indicated by CCS $(\mathrm{P})$, we observed the averages distribution related to teachers' self-assessment in relation to their incorporation of these new competences in their education practices. Figures 1 shows that teachers' self-evaluation is below students' evaluation, between 4,0 and 4,5 , identifying the need to revise this concept with teachers in order to potentiate best practices and consequently a better selfassessment and better students' evaluation in specific core competences such as: critical thinking, local and global citizenship, and life and career.

In Figure 2, similarly to the previous Figure, we present the data collected at CAP school, located in the countryside of the state of São Paulo, from students' perspective at different levels of education and also from teachers'. From Figure 2, we can find out that students at Elementary level 1 are, likewise Figure 1, those that best evidence the competences in teaching and learning activities carried out with the use of tablets, followed by High school and Elementary level 2, respectively. In teachers' self-evaluation, indicated by CAP (P), we observed, in the average distribution of self-evaluation, values between 4,31 and 3,81 , that is, lower values of self-assessment in relation to CCS school.

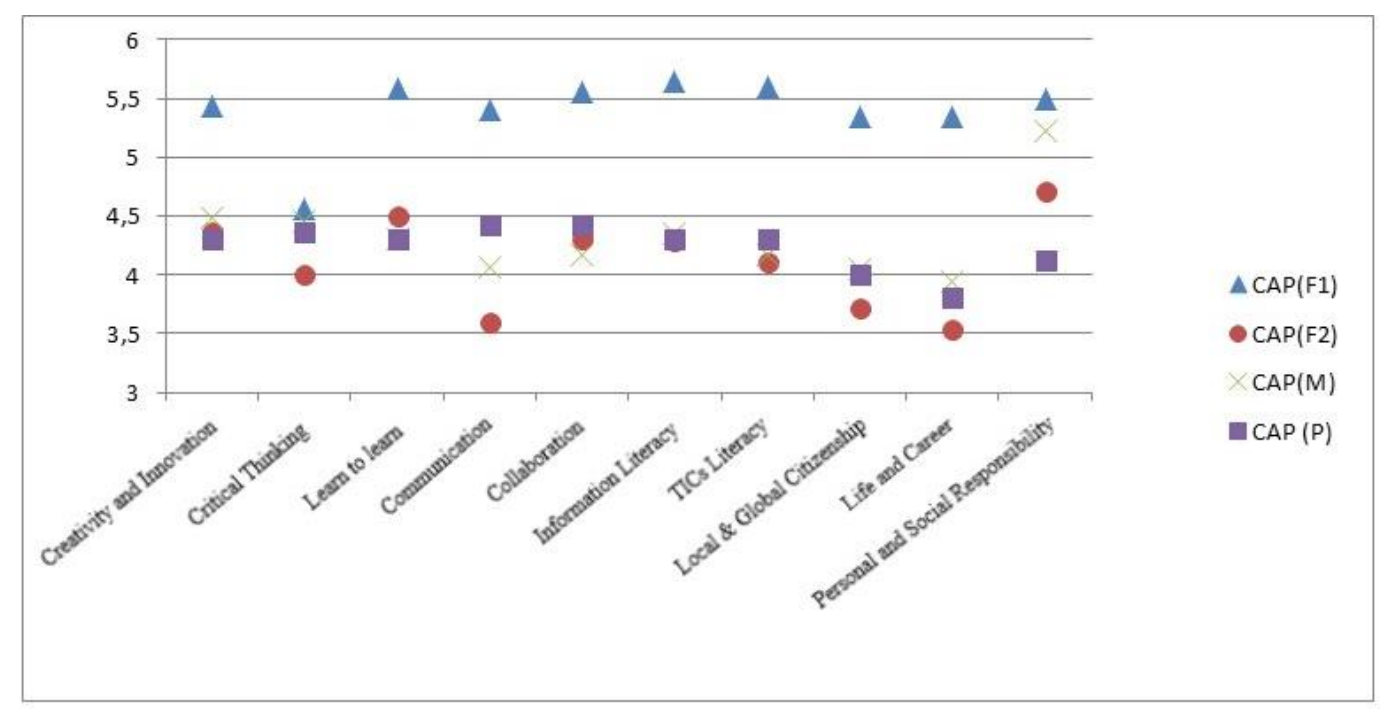

Figure 2: Observed students' average distribution and teachers' self-evaluation related to teaching and learning activities carried out with the use of tablets at different levels of education (CAP school)

At CSS school, only Elementary level 2 (CSS (F2)) and High School (CSS (M)) students took part, respectively, 26 and 38 students, as well as 7 teachers. It is noteworthy that this school began its activities with the use of tablets in these levels of education in 2017, being, therefore, an incipient project. The results presented in Figure 3, about Elementary and High School students' perception, are very close to most of the items related to the competences, except for the competences related to ICT literacy (ICT), local citizenship and personal and social responsibility. The difference in the average perception on literacy in ICTs seems to be reasonable, since for Elementary II school students the introduction of tablets can bring a larger and more comprehensive literacy component than 
for High School students. This was observed for Elementary levels 1 and 2 at CCS school (Figure 1) and, expressively, for Elementary level at CAP school (Figure 2).

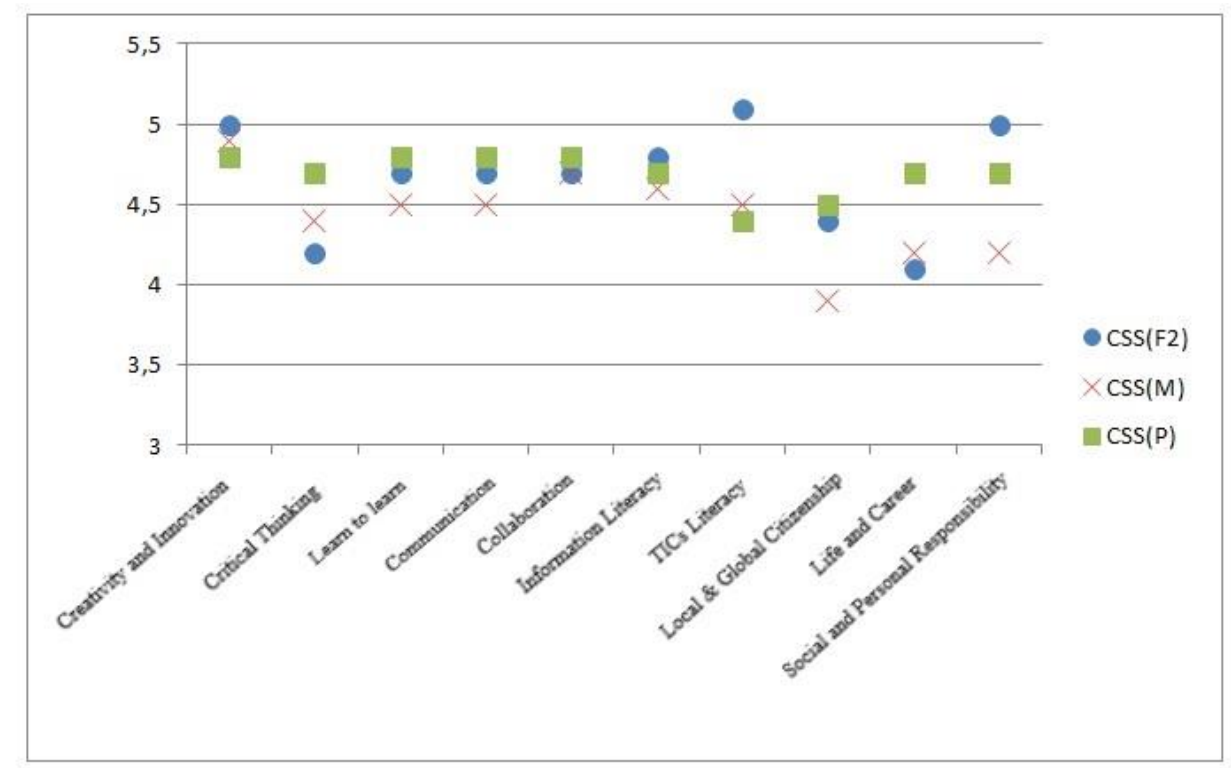

Figure 3: Observed students' average distribution and teachers' self-evaluation related to teaching and learning activities carried out with the use of tablets at different levels of education (CSS school)

Eight managers from the three schools participated in the survey. From these, we looked for indirect indicators related to the educational practices with the use of tablets. Three issues deserve special mention. When managers were asked whether m-learning characterizes innovative actions and allows for advances in pedagogical practice, $75 \%$ of them fully agreed with this statement, the same result was obtained when they were asked about the potential of the tablet to assist in the solution of complex and interdisciplinary problems (competences). All managers are unanimous in saying that students are motivated by the use of tablets, although $50 \%$ of managers question the applicability of the acquired knowledge.

\section{Conclusion}

We have presented in this paper a mapping of the national literature of the last three years (2014-2016) considering the main bases of scientific production on m-learning in the fields of Science and Mathematics in Basic Education. It was possible to identify that the great majority of scientific production analyzed follows the same direction of the recent works synthesized by Crompton (2017), that is, researches about the use of m-learning concentrate on activities based on traditional methods of teaching and learning that do not consider innovations and competences for the 21st century according to Binkley et al (2012). Thus, it is necessary to promote a new research agenda in order to promote more appropriate teaching and learning methods to the contexts of Science and Mathematics education.

Survey methodology carried out with the three schools in the state of São Paulo that have already started using tablets since 2012, and are in different maturity stages shows differences in teachers' self-assessment regarding how this promotes the competences for 
the 21st century in their teaching and learning activities. At CCS and CAP schools, teachers' self-evaluation results were very low. Further qualitative analysis should be undertaken to better understand the true causes of these factors. In general terms, we observed that although the practice of use of tablets is already established, competences of extreme importance as critical thinking seem not to be perceived in a very satisfactory way by students. As a contribution of this work, when analyzing the literature review associated with 21st century competencies (Binkley et al, 2012), there are some reflections that allow us to intensify the application of these competences in schools, so that they are aligned with teaching, learning and evaluation, as well as with the didactic strategies of use in technology in the education, not only by the mere use, but also by the intentionality when considering the stimulation to these competences through these resources.

\section{References}

ALMEIDA, Rosiney Rocha, 2016. Mobile learning no processo de ensino e aprendizagem de conteúdos de genética: proposta e análise com base na Teoria da Atividade. Tese de Doutorado. Programa de Ensino de Ciências e Matemática. Universidade Cruzeiro do Sul.

ARANTES, Hannderson and Seabra, Rodrigo, 2016. TME: Aplicativo M-Learning para o Estudo de Conceitos Matemáticos com Ênfase no ENEM. Simpósio Brasileiro de Informática na Educação-SBIE. p. 1.

BAEPLER, Paul, et al, 2014. It's not about seat time: Blending, flipping, and efficiency in active learning classrooms. Computers \& Education, v. 78, p. 227-236.

BINKLEY, Marilyn et al, 2012. Defining twenty-first century skills. In: Assessment and teaching of 21st century skills. Springer Netherlands. p. 17-66.

BISHOP, Jacob Lowell and Verleger, Matthew A., 2013. The flipped classroom: A survey of the research. In: ASEE National Conference Proceedings, Atlanta, GA. p. 1-18.

CROMPTON, Helen et al, 2017. The use of mobile learning in PK-12 education: A systematic review. Computers \& Education.

CROMPTON, Helen et al, 2016. The use of mobile learning in science: a systematic review. In Journal of Science Education and Technology, v. 25, n. 2, p. 149-160.

CROMPTON, Helen and Traxler, John (Ed.), 2015. Mobile Learning and Mathematics. Routledge.

FIORENTINI, D., 1994. Rumos da Pesquisa Brasileira em Educação Matemática: o caso da produção científica em cursos de Pós-Graduação. Tese Doutorado em Metodologia de Ensino. Campinas, FE/UNICAMP.

GARRISON, D. Randy and Vaughan, Norman D., 2008. Blended learning in higher education: Framework, principles, and guidelines. John Wiley \& Sons.

HONORATO, Eduardo et al, 2015. Computers in Education. Simpósio Brasileiro de Informática na Educação-SBIE. p. 1. 
RITZ, J. M., and Fan, S. C., 2015. STEM and technology education: International state-ofthe-art. In International Journal of Technology and Design Education, 25(4), 429-451.

ROMANOWSKI, J. P., \& Ens, R. T., 2006. As pesquisas denominadas do tipo "estado da arte" em educação. Revista Diálogo Educacional, 6(19), 37-50.

SMITH, Karl A. et al, 2005. Pedagogies of engagement: Classroom-based practices. In Journal of engineering education, v. 94, n. 1, p. 87-101.

TRILLING, B., and Fadel, C., 2009. 21st century skills: Learning for life in our times. John Wiley \& Sons.

UNESCO, 2012. Mobile Learning for Teachers in Latin America. Available at:< http://unesdoc.unesco.org/images/0021/002160/216081E.pdf>. Access on 18.apr.2016.

WEST, Mark and Chew, Han Ei, 2014. Reading in the mobile era: a study of mobile reading in developing countries. UNESCO. Available at:<

http://unesdoc.unesco.org/images/0022/002274/227436e.pdf > Access on 18.apr.2016. 87p. 